\title{
Peculiarities of aqua fitness exercises influence on the physical preparedness of women 30-49 years old using endogenous-hypoxic breathing method
}

Salnykova S.V. ${ }^{\text {ABCDE }}$, Furman Yu.M. ${ }^{2 A B C D E}$, Sulyma A.S. ${ }^{2 A B D E}$, Hruzevych I.V. ${ }^{2 A B D E}$, Gavrylova N.V. ${ }^{2 A B D E}$, Onyschuk V.Ye. ${ }^{2 \mathrm{ABDE}}$, Brezdeniuk O.Yu. ${ }^{2 \mathrm{ABDE}}$

${ }^{1}$ Vinnytsia Institute of Trade and Economics of Kyiv National University of Trade and Economics, Ukraine ${ }^{2}$ Vinnytsia Mykhailo Kotsiubynskyi State Pedagogical University, Ukraine

Authors' Contribution: A - Study design; B - Data collection; C - Statistical analysis; D - Manuscript Preparation; E - Funds Collection.

\begin{tabular}{|c|c|}
\hline \multicolumn{2}{|l|}{ Abstract } \\
\hline Purpose: & $\begin{array}{l}\text { To establish the complex influence of aqua fitness exercises and endogenous-hypoxic breathing techniques } \\
\text { on the physical preparedness of women } 30-49 \text { years old. }\end{array}$ \\
\hline Material: & $\begin{array}{l}\text { The study involved } 41 \text { women who had no previous experience of systematic physical education. } 2 \text { groups } \\
\text { were formed: MG1 ( } n=20 \text {, age } 30-36 \text { years old); MG2 }(n=210 \text {, age } 37-49 \text { years old). The experiment lasted } \\
\text { for } 24 \text { weeks. At classes, aqua fitness was applied to the method of endogenous-hypoxic respiration. At the } \\
\text { various stages of the study ( } 8,16 \text { and } 24 \text { weeks) it was examined physical preparedness of women. Frequency } \\
\text { of classes was } 3 \text { times a week. }\end{array}$ \\
\hline Results: & $\begin{array}{l}\text { Indicated in the need for dosage loading, taking into account the age factor and the level of physical and } \\
\text { functional preparedness of women. It was established that classes contribute to improvement: explosive } \\
\text { force; active flexibility of the spine; force dynamic endurance of the muscles of the lower extremities; speed- } \\
\text { strength endurance of muscles of the abdominal press; power static endurance of muscles of the back, neck } \\
\text { and buttock muscles; overall endurance. }\end{array}$ \\
\hline Conclusions: & $\begin{array}{l}\text { Aqua fitness exercises together with the endogenous-hypoxic respiration method contribute to the } \\
\text { improvement of the physical fitness of mature women. For women of } 30-36 \text { years old, improvements in } \\
\text { physical fitness were reported earlier compared with older women. } \\
\text { aqua fitness, physical qualities, physical fitness, women, mature age. }\end{array}$ \\
\hline
\end{tabular}

\section{Introduction}

Each age period of a person depending on sex is characterized by a specific alteration of the body [1]. In the body of women after 30 years, there are changes that are reflected in a decrease in the level of functional capabilities, indicators of physical development [2], the ability to exhibit physical qualities [3].

For women from 30 years of age, it is advisable to use physical education, which improves physical condition. This can be done through the following: stimulating aerobic energy supply processes [4]; increase in the energy cost of physical work $[5,6]$; reduction of gravitational influence on cartilage formation of joints [7]; quenching the body $[8,9]$. Such remedies include aqua fitness. Aqua fitness is characterized by a wide range of activities: health [10]; recreational [11]; conditioner [12]; educational and sports-oriented orientation [13]. There are a number of scientific papers on the methodology of using aqua fitness in the health-training process of different groups of the population. The authors found that:

- Aqua Power aerobics can be recommended for middle-aged females for the treatment of overweight and in the process of cardiopulmonary fitness improvement [14];

- $\quad$ Swimming, aqua-fitness, cycling and (Nordic)

(c) Salnykova S.V., Furman Yu.M., Sulyma A.S., Hruzevych I.V. , Gavrylova N.V. , Onyschuk V.Ye., Brezdeniuk O.Yu., 2018 doi:10.15561/18189172.2018.0407 walking are favourable sport disciplines for patients after laryngectomy for laryngeal cancer [15];

- Aqua walking appears to be a feasible alternative exercise modality to over-ground walking for cardiac rehabilitation and can be recommended for older adults with coronary artery disease and osteoarthritis [16];

- Aerobic activity in water seems to have had better effects on the mood state and on the physical efficiency than a comparable activity carried out in a gym. The aqua fitness programs are therefore highly recommendable as a sport for elderly women [17].

However, guidelines for the use of this remedy for workouts with women of 30-49 years old need to be completed.

In the practice of physical education, certain means are used that enhance the effectiveness of the health effect of physical exercises [18]. Specialists recommend to use method of creating in an organism the state of hypoxia. For this purpose it is used "Endogenic-01" [19]. The results of researches testify to successful application of the method of endogenous-hypoxic respiration (EHD) in a complex with physical exercises. The effectiveness of this application is proved by the improvement of the functional state of hockey players [20], swimmers [21], patients with asthma students [22]. The authors note that: 
- Water-based exercise is a training modality capable of enhancing cognitive function and quality of life through improved mental health in healthy adult women [23];

- Aging is accompanied by a decrease in aerobic capacity. Therefore, physical training has been recommended to soften the effects of advancing age [24];

- Both localized gymnastics and water aerobics can promote significant improvements in flexibility, balance and functional autonomy in elderly women after 12 weeks of training [25];

- Both water-based training (aerobic and combined) are effective in improving functional capacity and QoL perception of elderly women [26].

Other studies [2] have proved the effectiveness of complex application of aqua fitness and endogenoushypoxic respiration techniques when working with mature women. The results of researches are confirmed by improvement of their functional readiness [12].

Hypothesis. We predicted that the complex application of aqua fitness training and EHD techniques with women of 30-49 years old would increase their physical fitness.

The aim of the study: to establish the complex influence of aqua fitness training and endogenoushypoxic breathing techniques on the physical fitness of 37-49 years old women.

\section{Materials and methods.}

Participants. The experiment was attended by women of 30-49 years old $(n=41)$ who had no previous experience of systematic physical education. Two groups were formed - the first main (MG1, $\mathrm{n}=20$, age $-30-36$ years old) and the second main (MG2, $\mathrm{n}=21$, age $-37-49$ years old).

Organization of research. Physical fitness was studied using tests that characterize the following physical qualities: speed; explosive force; agility; force dynamic endurance muscles of the shoulder girdle; force dynamic endurance of the muscles of the lower extremities; speedstrength endurance of muscles of the abdominal press; power static endurance of muscles of the back, neck and gluteal muscles; active flexibility of the spine; general endurance.

The speed was determined on the basis of the test, "running at $30 \mathrm{~m}$ from a high start", an explosive force "jump in length from place", agility - "shuttle running $4 \times 9$ $m$ with the transfer of cubes". Force dynamic endurance of muscles of the shoulder girdle was determined by the number of flexions-extensions of the hands from the gymnastic bench. According to the index of flexionextension of the legs (the woman holds her hand behind the chair) evaluated the force dynamic endurance of muscles of the lower extremities. The speed-strength endurance of the muscles of the abdominal press was determined by the number of flexion-extensions of the legs: the woman lays on the back of the gymnastic bench; maximum tempo, duration of exercise - 15 seconds. Strength of static endurance of muscles of the back and neck was estimated by the duration of maximum lifting above the couch of straight arms and legs (arms and legs slightly dilated, a woman lying on her stomach). Strength of static endurance of the spinal muscles was estimated by the length of holding the posture: the woman is on the abdomen, her legs are bent in the knee joints at an angle of $45^{\circ}$, the legs are raised as much as possible above the couch and diluted by $10^{\circ}$. Active flexibility of the spine was determined by the inclination of the trunk ahead: the woman is on the stairs, the height of the swamp - 30 $\mathrm{cm}$. Overall endurance was estimated by the result of a 12-minute freestyle swimming test.

The research was carried out in stages: before the experiment began, and then in 8, 16 and 24 weeks later.

Frequency of classes was 3 times a week. In the process of training were used such aids as waterbaths, gloves, small and large dumbbells, nudls, boots, rubber shock absorbers, swimming boards [27]. The loading was dosed taking into account the age factor and level of physical and functional preparedness of women. Such dosage prevents the risk of negative effects of physical exercise in water on the body of women. The peculiarity of aqua fitness programs is the rational and systematic use of artificially created hypoxia and hypercapnia with the help of the apparatus "Endogenic-01". This technique was used at the beginning of each training session for 24 weeks in accordance with the route maps [19].

Statistical analysis. Summarizing numerical indices were presented that reflect the position of the center of empirical distributions and their scattering: arithmetic mean $(\mathrm{x})$; mean arithmetic mean error $(\mathrm{m})$; mean square (standard) deviation (S); dispersion (S2); coefficient of variation $(\mathrm{V})$.

The values of the sample from the general population were subject to the law of normal distribution, which was verified using Pearson's criterion. In order to determine the validity of the difference between the mean values it was used Student t-criterion. The difference was considered probable with a difference of $5 \%(\mathrm{p}<0.05)$.

\section{Results}

The complex application of aqua fitness exercises and endogenous-hypoxic respiration techniques generally results in an improvement in physical fitness of women 30-49 years old.

8 weeks after the start of classes in both groups of women (MG1, MG2), there were no probable changes in any of the indicators of physical fitness.

In women of the group MG1, after 16 weeks of training, had the following results: explosive force (by $8.15 \%$ ), active flexibility of the spine (by $73.28 \%$ ), dynamic endurance of the muscles of the lower extremities (by $50.98 \%$ ), speed-force endurance of muscles of abdominal press (by 23,94\%), power static endurance of muscles of the back and neck (by 80,35\%) and sphincter muscles (by $73,85 \%$ ). Also, the result of a 12 -minute swim test (Table 1 ) is likely to improve (by $44.06 \%$ ).

In the group MG1, after 24 weeks, there is a probable improvement in the results of the tests, which characterize the following: explosive force (by $9.46 \%$ ); dynamic force 
Table 1. Influence of aqua fitness exercises on the physical preparedness of women 30-49 years old (MG1, $n=20$, MG2, $n=21$ ) using endogenous-hypoxic respiration method

\begin{tabular}{|c|c|c|c|c|}
\hline Indexes & Group & $\begin{array}{l}\text { Mean values, } \bar{X} \pm \\
\text { Before exercises } \\
\text { begin }\end{array}$ & after 16 weeks & after 24 weeks \\
\hline \multirow{2}{*}{ Running for $30 \mathrm{~m}$ from a high start, sec } & MG1 & $6,76 \pm 0,10$ & $6,66 \pm 0,10$ & $6,63 \pm 0,10$ \\
\hline & MG2 & $7,31 \pm 0,10$ & $7,21 \pm 0,10$ & $7,19 \pm 0,10$ \\
\hline \multirow{2}{*}{ Jump in length from place, $\mathrm{cm}$} & MG1 & $152,15 \pm 3,26$ & $164,55 \pm 2,71 *$ & $166,55 \pm 2,40 *$ \\
\hline & MG2 & $134,43 \pm 3,08$ & $140,29 \pm 3,02$ & $145,71 \pm 2,72 *$ \\
\hline \multirow{2}{*}{ Shuttle running $4 \times 9 \mathrm{~m}$, sec } & MG1 & $12,89 \pm 0,09$ & $12,77 \pm 0,08$ & $12,71 \pm 0,08$ \\
\hline & MG2 & $13,59 \pm 0,27$ & $13,46 \pm 0,26$ & $13,46 \pm 0,26$ \\
\hline \multirow{2}{*}{$\begin{array}{l}\text { Bending-extension of the hands } \\
\text { (position lying) from the gymnastic } \\
\text { bench, the number of times }\end{array}$} & MG1 & $8,65 \pm 0,98$ & $10,85 \pm 0,98$ & $11,20 \pm 0,86$ \\
\hline & MG2 & $4,24 \pm 0,89$ & $5,76 \pm 0,89$ & $6,57 \pm 0,89$ \\
\hline \multirow{2}{*}{$\begin{array}{l}\text { Bending-extension of the legs (standing } \\
\text { position, holding the back of the chair) } \\
\text { the number of times }\end{array}$} & MG1 & $25,60 \pm 2,21$ & $38,65 \pm 3,01^{*}$ & $44,95 \pm 2,28 *$ \\
\hline & MG2 & $18,05 \pm 1,48$ & $21,52 \pm 1,30$ & $26,33 \pm 0,89 *$ \\
\hline \multirow{2}{*}{$\begin{array}{l}\text { Bending-extension of the legs (position } \\
\text { lying on the gymnastic bench), the } \\
\text { number of times for } 15 \mathrm{sec} \text {. }\end{array}$} & MG1 & $14,20 \pm 0,68$ & $17,60 \pm 0,43^{*}$ & $18,25 \pm 0,43^{*}$ \\
\hline & MG2 & $12,67 \pm 0,65$ & $14,14 \pm 0,65$ & $15,29 \pm 0,77^{*}$ \\
\hline \multirow{2}{*}{ Position $1^{\#}$, sec } & MG1 & $46,30 \pm 3,94$ & $83,50 \pm 7,57 *$ & $87,65 \pm 7,26 *$ \\
\hline & MG2 & $35,67 \pm 2,07$ & $41,14 \pm 2,01$ & $60,81 \pm 1,42 *$ \\
\hline \multirow{2}{*}{ Position $2^{\# \#, ~ s e c ~}$} & MG1 & $55,45 \pm 4,12$ & $96,40 \pm 7,93^{*}$ & $103,20 \pm 7,20 *$ \\
\hline & MG2 & $44,62 \pm 4,14$ & $55,57 \pm 3,96$ & $77,33 \pm 3,67^{*}$ \\
\hline \multirow{2}{*}{ Tilting forward (standing position), $\mathrm{cm}$} & MG1 & $6,55 \pm 0,80$ & $11,35 \pm 0,74^{*}$ & $12,70 \pm 0,68 *$ \\
\hline & MG2 & $2,90 \pm 0,41$ & $4,10 \pm 0,47$ & $5,52 \pm 0,59 *$ \\
\hline \multirow{2}{*}{$\begin{array}{l}\text { Test of a 12-minute swimming by } \mathrm{K} \text {. } \\
\text { Cooper, } \mathrm{m}\end{array}$} & MG1 & $219,00 \pm 13,84$ & $315,50 \pm 15,38^{*}$ & $347,75 \pm 15,38^{*}$ \\
\hline & MG2 & $215,48 \pm 13,31$ & $266,67 \pm 10,35^{*}$ & $305,52 \pm 14,08^{*}$ \\
\hline
\end{tabular}

Note. * - statistically significant differences with respect to the initial data; \# position 1 - the woman lies on the couch (on the stomach): legs and arms are slightly dilated and raised up; \#\# position 2 - the woman lays on the couch (on the stomach) and holds her hand behind the couch: her legs are diluted by 10 degrees and bent at knees at an angle of 45 degrees; feet maximally raised above the couch.

endurance of the muscles of the lower extremities (by $75,59 \%$ ); speed-strength endurance of muscles of the abdominal press (on $28,52 \%$ ); power static endurance of the muscles of the back and neck (by $89.31 \%$ ) and the spinal muscles (by $86.11 \%$ ); active flexibility of the spine (by $93.89 \%$ ); general endurance (by $58.79 \%$ ).

In the group MG2, after 16 weeks, only the result of control test, which represents overall endurance (by $23.76 \%$ ), is likely to be improved. The remaining indicators remained unchanged.

In the group MG2 at the end of the study, the indicators have increased significantly: explosive force of $8.40 \%$; speed-strength endurance of muscles of the abdominal press by $45,91 \%$; speed-strength endurance of muscles of the abdominal press by $20,68 \%$; power static endurance of muscles of the back and neck on by $70,49 \%$; femoral muscles by $73.32 \%$; active flexibility of the spine by
$90,16 \%$. In the group MG2 within 24 weeks, the result of the test, which characterizes overall endurance, has probably increased (by $37.93 \%$ ).

\section{Discussion.}

The results of testing the physical fitness of women aged 30-49 years are confirmed by the results of research of scientists about age changes: level of physical capacity [22]; indicators of physical development [2]; functional capabilities [28]. There is a decrease in the physical state of the body as a whole [5].

The information of other authors $[7,20,21]$ on the effectiveness of the application of endogenous-hypoxic respiration method in a complex with physical exercises has been confirmed and supplemented.

The results of the research [27] prove the positive effect of training exercises with swimming using force 
exercises from aqua fitness and the technique of EHD for the special physical fitness of swimmers aged 11-12 years. Unlike the above, our research in general was intended to justify and develop a program of aqua fitness training to improve the physical condition of mature women.

For the first time, we scientifically grounded and developed the program of aqua fitness classes for women aged 30-49 years. The peculiarity of such program is the use of endogenous-hypoxic respiration method [12].

Our program involves a gradual increase in exercise designed to develop overall endurance. At the initial stages of the woman's work twice a week, they worked mainly for the development of strength endurance, and once - for the general. In the main period, the number of classes for the development of general endurance gradually increased. At the same time, the load was dosed taking into account the age factor, the level of physical and functional preparedness of women. The method of endogenous-hypoxic respiration was integrated into the program to enhance the effect of exercise in water.

The results of our studies have shown that the use of endogenous-hypoxic respiration techniques in aqua fitness classes with women aged 30-49 years contributes to improving the manifestation of their physical qualities. Women of 30-36 years old have such changes occurred earlier compared with women aged 37-49 years.

For the first time, experimentally proved the positive influence of aqua fitness exercises using the method of endogenous-hypoxic breathing on the physical condition of women aged 30-49 years. The information of other authors $[3,12,29,30]$ about the positive influence of aqua fitness exercises on the physical condition of mature women has been confirmed and supplemented.

The advantages of our methodology are the results of the physical fitness of women after the completion of the molding experiment. After 24 weeks from the beginning of exercises in women recorded an increase in the indicators that characterize: explosive force; force dynamic endurance of the muscles of the lower extremities; speed-strength endurance of muscles of the abdominal press; power static endurance of muscles of the back, neck and gluteal muscles; active flexibility of the spine; general endurance.

The results of control tests in the groups MG1 and MG2 supplement the scientific information of other authors $[3,13,27,31]$ on the effectiveness of aqua fitness in training sessions.

\section{Conclusions}

The results of studies have shown that aqua fitness classes using endogenous-hypoxic respiration techniques help to improve the physical fitness of mature women. For women aged 30-36 years, improvements in physical fitness were recorded earlier compared with women of $37-49$ years old.

\section{Financing}

The research was carried out in accordance with the plan of research work of the Department of Biomedical Fundamentals of Physical Education and Rehabilitation of Vinnytsia Mykhailo Kotsiubynskyi State Pedagogical University for 2017-2018 "Integrated application of physical education and methods of endogenous-hypoxic respiration" to improve the physical condition of persons in the Podillya region”.

\section{Conflict of interest.}

The authors state that there is no conflict of interest.

\section{References}

1. Orozco Ríos AM, López Velarde Peña T, Martínez Gallardo Prieto L. Estrategias para un envejecimiento exitoso [Strategies for a successful aging]. Revista Española de Geriatría y Gerontología. 2016;51(5):284-9. doi:10.1016/j. regg.2015.10.001

2. Salnykova SV. Comparative characteristics of the physical condition of women 30-49 years old of physical fitness indicators, depending on the fat content of the body mass. Fizichne vikhovannia, sport i kul'tura zdorov'ia $u$ suchasnomu suspil'stvi, 2017; 1: 77 - 82. (in Ukrainian)

3. Salnykova S, Furman Yu. Comparative characteristic of physical preparedness of women 30-49 years old, depending on age. Fizichna kul'tura, sport ta zdorov'ia nacii, 2017; 3(22): 154-158. (in Ukrainian)

4. Leonska-Duniec A, Jastrzebski Z, Jazdzewska A, Moska W, Lulinska-Kuklik E, Sawczuk M, et al. Individual Responsiveness to Exercise-Induced Fat Loss and Improvement of Metabolic Profile in Young Women is Associated with Polymorphisms of Adrenergic Receptor Genes. Journal of Sports Science and Medicine. 2018;17(1):134-144.

5. Ferrara N, Pisanelli P, Voza M, Abete P, Leosco D, Filippelli A, Rengo F. The aging heart and exercise training. Archives of Gerontology and Geriatrics. 2002; 35(SUPPL. 8): 145-

\section{6. doi:10.1016/S0167-4943(02)00122-X}

6. Leonska-Duniec A, Grzywacz A, Jastrzebski Z, Jazdzewska A, Lulinska-Kuklik E, Moska W, et al. ADIPOQ polymorphisms are associated with changes in obesityrelated traits in response to aerobic training programme in women. Biology of Sport. 2018;35(2):165-173. doi:10.5114/ biolsport.2018.72762

7. Sulyma A, Bohuslavska V, Furman Yu, Galan Ya, Doroshenko E, Pityn M. Effectiveness of the application of the endogenous-hypoxic breathing technique in the physical training of the qualified field hockey players. Journal of Physical Education and Sport. 2017; 17(4): 2553 - 2560.

8. Charansonney OL. Physical activity and aging: A life-long story. Discovery Medicine. 2011; 12(64): 177-185

9. Zarebska A, Jastrzebski Z, Moska W, Leonska-Duniec A, Kaczmarczyk M, Sawczuk M, et al. The AGT Gene M235T Polymorphism and Response of Power-Related Variables to Aerobic Training. Journal of Sports Science and Medicine. 2016;15(4):616-624.

10.Antonio J, Stout JR. Supplements for endurance athletes. Champain, Illinois: Human Kinetics; 2003.

11.Kenney LW, Wilmore JH, Costill DL. Physiology of Sport and Exercise. Champaign: Human Kinetics, 2012.

12.Salnykova S, Hruzevych I, Bohuslavska V, Nakonechnyi I, Kyselytsia O, Pityn M. Combined application of aquafitness 
and the endogenous-hypoxic breathing technique for the improvement of physical condition of 30-49-year-old women. Journal of Physical Education and Sport. 2017; 17(4): 2544-2552. doi:10.7752/jpes.2017.04288

13.Zhuk A, Habinets T. Efficiency of Aqua Fitness in Physical Education of Junior Schoolchildren. Molodizhnij naukovij visnik, 2012; 7: 60-63.

14.Bielec G, Kwasna A, Gaworska P. The influence of Aqua Power aerobics on body mass reduction in middle-aged, overweight women. Turkish Journal of Physical Medicine and Rehabilitation. 2017;63(4):293-298. doi:10.5606/ tftrd.2017.853

15.Buntzel J, Buntzel H, Mucke R, Besser A, Micke O. Sport in the Rehabilitation of Patients After Total Laryngectomy. Anticancer Research. 2016;36(6):3191-3194.

16.Lee JY, Joo KC, Brubaker PH. Aqua walking as an alternative exercise modality during cardiac rehabilitation for coronary artery disease in older patients with lower extremity osteoarthritis. Bmc Cardiovascular Disorders. 2017;17. doi:10.1186/s12872-017-0681-4

17.Scurati R, Benedini S, Michielon G, Invernizzi PL, Zannini L, Alberti G. Controlled intensity aerobic activity in water and in the gym: effects on mood and physical efficiency in third age women. Medicina Dello Sport. 2016;69(2):215227.

18.Kolchinskaya AZ. Interval Hypoxic Training in Sports. Hypoxia Med. J., 1993; 2: 28 - 33.

19.Khodorovs'kij GI, Koliasko IV, Furkal IeS, Koliasko NI, Kuznecova OV, Iasins'ka OV. Endogenous-hypoxic breathing. Chernivtsi: Theory and practice; 2006. (in Ukrainian)

20.Furman Yu, Sulyma A. nfluence of endogenous-hypoxic respiration on restoration of the function of the cardiovascular system of qualified hockey players on the grass after dosed physical activity. Molodizhnij naukovij visnik, 2015; 18: 240 - 245. (in Ukrainian)

21.Hruzevych I, Bohuslavska V, Kropta R, Galan Ya, Nakonechnyi I, Pityn M. The effectiveness of the endogenous-hypoxic breathing in the physical training of skilled swimmers. Journal of Physical Education and Sport (JPES), 2017; 17 (3): 10091016. doi:10.7752/jpes.2017.s3155

22.Onishchuk VIe. Application of endogenous-hypoxic respiration in the system of rehabilitation of students with bronchial asthma. Cand. Diss. Vinnitsa; 2012. (in Ukrainian)

23.Ayan C, Carvalho P, Varela S, Cancela JM. Effects of WaterBased Exercise Training on the Cognitive Function and
Quality of Life of Healthy Adult Women. Journal of Physical Activity \& Health. 2017;14(11):899-904. doi:10.1123/ jpah.2017-0036

24. Costa RR, Reichert T, Coconcelli L, Simmer NM, Bagatini NC, Buttelli ACK, et al. Short-term water-based aerobic training promotes improvements in aerobic conditioning parameters of mature women. Complementary Therapies in Clinical Practice. 2017;28:131-135. doi:10.1016/j. ctcp.2017.06.001

25.Mazini ML, Aidar FJ, Moreira OC, de Matos DG, de Oliveira CEP, Venturini GRD, et al. Comparison of the effect of two physical exercise programs on the functional autonomy, balance and flexibility of elderly women. Medicina Dello Sport. 2017;70(3):288-298. doi:10.23736/s00257826.17.03012-5

26.Silva MR, Alberton CL, Portella EG, Nunes GN, Martin DG, Pinto SS. Water-based aerobic and combined training in elderly women: Effects on functional capacity and quality of life. Experimental Gerontology. 2018;106:54-60. doi:10.1016/j.exger.2018.02.018

27.Golovkina V, Salnykova S. Dynamics of indicators of aerobic and anaerobic productivity of an organism of swimmers of 11-12 years under the influence of training sessions with the use of aqua fitness elements and interval hypoxic training. Visnik Prikarpats'kogo universitetu, 2017; 25-26: 66-72. (in Ukrainian)

28.Salnykova S. Comparative characteristics of the physical training of women between 30 and 49 years of age based on indicators of physical training depending on the body weight fat component content. Fizichne vikhovannia, sport $i$ kul'tura zdorov'ia u suchasnomu suspil'stvi, 2017; 1: 77-82.

29.Lazareva O, Vasylenko Y, Galan Y, Dotsiuk L, Tsybanyuk O. Evaluation of the effectiveness of the application of physical rehabilitation program for premature infants with motor disorders of various genesis according to the INFANIB testing scale. J Phys Educ Sport, 2017;17(4):2392-2398.

30.Lazareva O, Aravitska M, Andrieieva O, Galan Y, Dotsyuk L. Dynamics of physical activity status in patients with grade I-III obesity in response to a physical rehabilitation program. J Phys Educ Sport, 2017;17(3):1960-1965.

31.Ivko IA, Pozdeeva EA. The comparison of the growth rate of the morphofunctional status and physical fitness in women of young and mature age at the initial stage of health-improving aerobics classes. Human. Sport. Medicine, 2016;16(4):5-17. doi:10.14529/hsm160401 


\section{Information about the authors:}

Salnykova S.V.; (Corresponding author); http://orcid.org/0000-0003-4675-6105; aqvasveta@ukr.net; Vinnytsia Institute of Trade and Economics of Kyiv National University of Trade and Economics; Soborna st., 87, Vinnytsia, 21050, Ukraine.

Furman Yu. M.; http://orcid.org/0000-0002-5206-7712; furman-dok@ukr.net; Vinnytsia Mykhailo Kotsiubynskyi State Pedagogical University; Ostroz'koho st., 32, Vinnytsia, 21100, Ukraine.

Sulyma A.S.; http://orcid.org/0000-0003-1858-0085; allasulyma16.83@gmail.com; Vinnytsia Mykhailo Kotsiubynskyi State Pedagogical University; Ostroz'koho st., 32, Vinnytsia, 21100, Ukraine.

Hruzevych I. V.; http://orcid.org/0000-0002-3003-4549; gruzevich_irina@ukr.net; Vinnytsia Mykhailo Kotsiubynskyi State Pedagogical University; Ostroz'koho st., 32, Vinnytsia, 21100, Ukraine.

Gavrylova N.V.; http://orcid.org/0000-0001-6209-5875; gavrilova.natal83@gmail.com; Vinnytsia Mykhailo Kotsiubynskyi State Pedagogical University; Ostroz'koho st., 32, Vinnytsia, 21100, Ukraine.

Onyschuk V.Ye.; http://orcid.org/0000-0002-9615-6653; vitapilgun@yandex.ru; Vinnytsia Mykhailo Kotsiubynskyi State Pedagogical University; Ostroz'koho st., 32, Vinnytsia, 21100, Ukraine.

Brezdeniuk O.Yu.; http://orcid.org/0000-0003-0844-8777; sandrikk86@gmail.com; Vinnytsia Mykhailo Kotsiubynskyi State Pedagogical University; Ostroz'koho st., 32, Vinnytsia, 21100, Ukraine.

Cite this article as: Salnykova SV, Furman YuM, Sulyma AS, Hruzevych IV, Gavrylova NV., Onyschuk VYe, Brezdeniuk OYu. Peculiarities of aqua fitness exercises influence on the physical preparedness of women 30-49 years old using endogenous-hypoxic breathing method. Pedagogics, psychology, medical-biological problems of physical training and sports, 2018;22(4):210-215. doi:10.15561/18189172.2018.0407

The electronic version of this article is the complete one and can be found online at: http://www.sportpedagogy.org.ua/index.php/PPS/issue/archive

This is an Open Access article distributed under the terms of the Creative Commons Attribution License, which permits unrestricted use, distribution, and reproduction in any medium, provided the original work is properly cited (http://creativecommons.org/licenses/by/4.0/deed.en).

Received: 20.01.2018

Accepted: 27.02.2018; Published: 30.08 .2018 